Abstracta Iranicacta Iranica

Revue bibliographique pour le domaine irano-aryen

Volume 34-35-36 | 2017

Comptes rendus des publications de 2011-2013

\title{
Giovanni Bergamini. Babylon in the Achaemenid and Hellenistic Period: The Changing Landscape of a Myth
}

\section{Astrid Nunn}

\section{(2) OpenEdition}

1 Journals

\section{Édition électronique}

URL : http://journals.openedition.org/abstractairanica/41440

DOI : 10.4000/abstractairanica.41440

ISSN : 1961-960X

Éditeur :

CNRS (UMR 7528 Mondes iraniens et indiens), Éditions de l'IFRI

Référence électronique

Astrid Nunn, "Giovanni Bergamini. Babylon in the Achaemenid and Hellenistic Period: The Changing Landscape of a Myth », Abstracta Iranica [En ligne], Volume 34-35-36 | 2017, document 11, mis en ligne le 15 juillet 2016, consulté le 26 septembre 2020. URL : http://journals.openedition.org/ abstractairanica/41440 ; DOI : https://doi.org/10.4000/abstractairanica.41440

Ce document a été généré automatiquement le 26 septembre 2020.

Tous droits réservés 


\title{
Giovanni Bergamini. Babylon in the Achaemenid and Hellenistic Period: The Changing Landscape of a Myth
}

\author{
Astrid Nunn
}

\section{RÉFÉRENCE}

Giovanni Bergamini. «Babylon in the Achaemenid and Hellenistic Period: The Changing Landscape of a Myth». Mesopotamia, 46, 2011, p. 23-34.

1 Il est généralement accepté que les différences architecturales entre la Babylone néobabylonienne et perse étaient peu importantes. Ces différences consisteraient en la destruction de la zikkurat par Xerxes et le détournement de l'Euphrate aux alentours de 458 av. J.-C. L'A. analyse ces deux points et arrive à de nouvelles conclusions. Xerxes n'a pu détruire le bâtiment trop imposant qu'est une zikkurat. Peut-être avait-il simplement rendu l'accès aux étages impossibles en détruisant les rampes. Il est tout de même très probable que la zikkurat était en mauvais état à la fin de l'époque achéménide.

Quant au détournement de l'Euphrate décrit par Hérodote, rien ne l'assure. Des recherches récentes sur la géomorphologie de Babylone (voir dans le même volume) ont mis au jour l'existence de nombreux canaux à l'intérieur des murs. Ils témoignent, comme partout ailleurs en Babylonie, de la préoccupation des habitants de Babylone à se pourvoir en eau. L'A. s'oppose donc à la théorie d'un détournement de fleuve. Le seul quartier où la continuité réellement existe est celui du Merkes. En résumé : les changements - le déclin de la zikkurat et la construction du «Perserbau»- sont directement liés au nouveau pouvoir et sont effectivement peu nombreux. 


\section{AUTEURS}

\section{ASTRID NUNN}

Université de Munich 